\title{
MARKETING AND MARKETING COMMUNICATIONS
}

\author{
DOI: 10.46340/eujem.2021.7.1.16
}

Halyna Tarasiuk, ScD in Economics

ORCID ID: https://orcid.org/0000-0001-5112-102x

Zhytomyr Polytechnic State University, Ukraine

Olha Kovalchuk

ORCID ID: https://orcid.org/0000-0003-4147-7844

Zhytomyr Polytechnic State University, Ukraine

\section{CREATING A STRONG BRAND POSITIONING}

Today, the place of brands in the modern economy is growing every day, which requires the development of new approaches to managing the positioning of the portfolio of companies' brands. With the development of market and competitive relations, the issue of brand positioning has become relevant. Gaining a certain market share is a major factor in a successful marketing strategy, which depends on the strength of product positioning and marketing activities of the company. Company positioning is the development and consolidation of a certain image of a brand or company in the minds of customers. Positioning helps to pay attention to the unique features of a product or service and allows you to distinguish it from competitors. This topic requires further research by researchers, brand managers and specialists in this field to identify a number of theoretical shortcomings. The purpose of the paper is to determine the brand position to develop a strategy for positioning the brand portfolio. Methodology. The following tools are used in the work: marketing research, goal setting; as well as reflected models (Rossiter-Percy matrix and brand molecule); the method of generalization of the information, which resulted to the development of a matrix of positioning of a portfolio of brands is reflected. Results. The issue of brand portfolio positioning management is studied. It is noted that given the importance of the consumer, it is advisable to consider the positioning of the portfolio of brands of the enterprise not just as a definition of its place, but also as the point of view of the consumer on the brand. The system of criteria for assessing the brand 's position in the market is studied. An algorithm for brand positioning is formed based on the use of a three-level Rossiter-Pearson model, which is based on the ratio of brand awareness and attitude to it. The matrix of brand portfolio positioning for the trademark 'Rud' is formed.

Key words: brand, positioning, branding, brand molecule, positioning strategy, consumer.

Introduction. Branding is an important aspect that must be taken into account when formulating a development strategy for any enterprise, because it connects with the target audience, it contributes to a number of goals of socio-economic development, and reflects, to some extent, individuality companies.

Every company, even if it is a small firm, needs a clear positioning strategy. This is useful both for the company's employees (they better understand what the brand is and how to better connect with customers) and for consumers - they know what the brand is better than others, and what benefits they will gain. Positioning helps emphasize the individuality of the brand.

The main advantage of brand positioning in a competitive niche is the ability to successfully promote the product. Properly designed communication strategy forms a beautiful image of the company and emphasizes the advantages and competitive advantages of the product. Positioning helps to form a loyal target audience and strengthen the brand's position in the market.

Brand positioning - the place in the market occupied by the brand in relation to competitors, as well as the set customer needs and perceptions; part of the brand identity that should be actively used to "detach" from competitors. There are some basic ideas and concepts in positioning.

1. Positioning refers more to long-term strategy than short-term tactics.

2. Positioning is carried out in consciousness. Positioning is what a consumer thinks about a company, product or service. Therefore, it is crucial that the perspective position should be determined by the consumer and not by the company. 
3. Positioning is based on benefits.

4. In a segmented market, it is very important to understand the position that a company with its offer takes in the minds of consumers of all significant market segments.

5. Positioning is a relative concept. Products and brands take positions relative to competing products and brands. The quality and level of service is assessed in relation to what is offered by competitors ${ }^{1}$.

Presentation of the main research material.

The place of brands in the modern economy is growing every day, which requires the development of new approaches to managing the positioning of the portfolio of brands of companies. This topic requires further research by scientists, brand managers and specialists in this field to identify a number of theoretical shortcomings. Positioning is traditionally viewed as a marketing design technology. On the one hand, it takes into account the performance of the product or service and the target audience, so positioning strategies are designed to answer the question - what are we advertising and for whom? On the other hand, positioning technology is closely related to the creation of a creative strategy in advertising, and therefore, with speech technologies - in this case, the first place comes to the question - how do we advertise?

The decision to use one or another method of developing positioning directly depends on the marketers of the organization. In the work of J. Rossiter and L. Percy "Advertising and promotion", which is devoted to advertising and promotion of FMCG (fast moving consumer goods), positioning technology determines the key content of advertising, allowing you to show the consumer what a brand is, what its benefits. The authors describe a three-level positioning model. Consider three levels of this model:

1). Macromodel $\mathrm{X}-\mathrm{Y}-\mathrm{Z}$, this formula means the main positioning parameters: $\mathrm{Y}$ - to whom the advertising message is defined; $\mathrm{X}$ - which product is offered; $\mathrm{Z}$ - what benefits (assistance) does this product offer to consumers. Differentiated positioning allows you to determine the brand in terms of observation: where $\mathrm{X}$ decides what will produce to occupy a central position in the market or just a niche. $\mathrm{YZ}$ - involves making decisions about who represents the voice figure in the messages transmitted through the IMC (integrated marketing communications) - consumers of the product;

2). Mesomodel I-D-U is a new model that focuses on benefits. The model is based on eight types of consumer motives. Consumer motives underlie benefit. The mesomodel is based on three key requirements: the importance of benefit (Importance) - the emotional weight of the place of benefit; product presentation of important benefits (delivery); Uniqueness (Uniqueness) - the ability to imagine the benefits that are better than competitors. Evaluation at this level is performed for each target audience separately ${ }^{2}$.

3). Micromodel a-b-e - focus on benefits. According to the formula a-b-e, you need to decide what to pay attention to the first time - on the characteristics of the product (attribute), the benefits of products (benefits) on emotions (emotion). Based on these concepts and their complexes, you can use at least three focal points and three links in advertising:

1. Emphasis on product characteristics is appropriate if:

- experienced target audience;

- subject of advertising - elusive service;

- The emphasis on characterization is an alternative emphasis on emotion for homogeneous brands. The meaning of this strategy is that with the help of certain characteristics it is possible to distinguish a brand from a number of similar ones, as it manages some additional authorities;

2. Emphasis on benefits is used if:

- the benefits of the brand are difficult to copy;

- negative motivation when buying;

- brand recovery is based on emotions;

3. Emphasis on pure emotions of justification by the fact that:

- the benefits of the brand are difficult to copy;

- positive motivation when using;

- brand restoration is based on characteristics ${ }^{3}$.

Characteristics are actually a description of how a product works and what benefits it brings. They serve as a so-called 'reason to believe'. A large number of marketers promoting consumer goods (FMCG) scoff at attempts to describe the "unique" properties of long-known mass products. In the marketing

\footnotetext{
${ }^{1}$ Aaker, D. (1996). Building Strong Brands. New York: The Free Press.

${ }^{2}$ Kapferer, J.-N. (2008). New strategic brand management: creating and sustaining brand equity long. London and Philadelphia: Kogan page.

${ }^{3}$ Ibid.
} 
of consumer goods, this approach does not work. But for technological devices and innovative services, key characteristics can be an important advantage.

The choice of focus, according to the authors, depends on the characteristics of the target audience and the advertising product itself. Based on the above data, we will form a model of brand portfolio positioning to determine the market position (Table 1).

Table 1

Brand portfolio positioning model for determining the market position

\begin{tabular}{|c|c|c|l|}
\hline Model & Indicator & Selection of criteria & \multicolumn{1}{c|}{ Characteristic } \\
\hline \multirow{2}{*}{ Macromodel X-Y-Z } & $\mathrm{X}$ & Market position; & $\begin{array}{l}- \text { occupying a central position; } \\
\text { occupation of a niche; }\end{array}$ \\
\cline { 2 - 4 } & $\mathrm{YZ}$ & Key figure; & $\begin{array}{l}- \text { consumer; } \\
\text { product; }\end{array}$ \\
\hline \multirow{2}{*}{\begin{tabular}{c} 
Mesomodel I-D-U \\
\cline { 2 - 4 }
\end{tabular}} & $\mathrm{I}$ & Importance; & emotional weight of benefits; \\
\cline { 2 - 4 } & $\mathrm{U}$ & Delivery; & The ability of a product to benefit; \\
\hline \multirow{2}{*}{$\begin{array}{c}\text { Micromodel } \\
\text { a-b-e }\end{array}$} & $\mathrm{a}$ & Uniqueness; & $\begin{array}{l}\text { The ability to imagine benefits that are better } \\
\text { than competitors; }\end{array}$ \\
& attribute; & $\begin{array}{l}\text { Emphasis on product characteristics; } \\
\text { Emphasis on the benefits associated with } \\
\text { this product characteristic; }\end{array}$ \\
\cline { 2 - 4 } & $\mathrm{b}$ & benefit; & - emphasis on benefits; \\
\cline { 2 - 4 } & emotion; & $\begin{array}{l}\text { emphasis on the emotion associated with } \\
\text { benefit; } \\
\text { emphasis on emotions. }\end{array}$ \\
\hline
\end{tabular}

Source: compiled by the author according to ${ }^{l}$

Positioning a product or brand is giving a specific image to a brand that translates values, it is a wellconstructed strategic process that helps to take and strengthen its position in the market, in our case it is to determine the location of the brand or brand portfolio. The presence of clear positioning allows you to effectively implement communication with the consumer. A brand portfolio is a complete set of brands managed by a company, maintaining and developing the identity of each brand ${ }^{2}$.

Brand portfolio management is a continuous process, which on the one hand - ensures the satisfaction of the target audience, and on the other - increases the capitalization of brands in the company for a long time. Marketer S. Hill proposed a new approach to the formation of a brand portfolio - a "molecule" of the brand, which allows you to clearly define the company's goals and positioning of the brand portfolio, contributing to the appropriate perception of the brand by consumers.

Today you rarely see a situation when a company owns only one brand, for the promotion of which it directs all its efforts. Typically, companies have to manage an entire portfolio of brands that includes branded houses, sub-brands, endorsed brands, umbrella brands, and other members of this branched family. In addition, each company has to track not only its own but also other brands with which its products are associated with partnerships or sponsorships.

Brand portfolio management is a continuous process, which on the one hand - ensures the satisfaction of the target audience, and on the other - increases the capitalization of brands in the company for a long time.

American researchers Chris Lederer and Sam Hill proposed to take into account all these factors and proposed a new approach to the formation of a brand portfolio. In their book, The Infinite Asset, they described a mechanism for creating three-dimensional models that resemble molecules, which allows you to clearly define the company's goals and the positioning of the brand portfolio, contributing to the appropriate perception of the brand by consumers; each atom in them corresponds to one brand (own or someone else's), which in some way influences the consumer's decision to buy the product under study ${ }^{3}$.

\footnotetext{
${ }^{1}$ Studref (2021). Позиционирование <https://studref.com/348316/marketing/pozitsionirovanie> (2021, January, 05).

2 Domnin, V. N. (2020). Branding: textbook and workshop for secondary vocational education. Moscow: Yurayt, 411.

${ }^{3}$ Marketing.Webstandart.Net (2021). Molecular Branding <http://marketing.webstandart.net/node/1268>

(2021, January, 05).
} 
It is recommended to use a visual model used in chemistry to demonstrate molecular structures to analyze brands in the environment. Each brand is an atom, its size depends on the importance of the brand in the portfolio. Relationships between brands are displayed by segments of straight lines. The thickness of the segments corresponds to the strength of the interaction between brands.

The construction of the "molecule" of the brand portfolio makes it possible to identify brands that belong to the brand portfolio and divide them into the branded houses, sub-brands, endorsed brands and houses of brands. The branded house is the brand of the manufacturer to which the "brand molecule" is built.

Assessment of the "brand molecule" of the brand portfolio helps to determine the state and position of the company in the market among a number of competitors and has an impact on the efficiency of the enterprise. The strong position of the brand allows you to improve or change in a positive way the attitude of consumers to products and create a loyal attitude.

Analysis of the brand's position in the market with the specified participants in the brand portfolio (the branded houses, sub-brands, endorsed brands and houses of brands) is determined using our proposed system of criteria: commodity group (key attributes of the brand; The range of the brand; Economic benefits; The uniqueness of the brand; Product quality); Sales activities (Company reputation; Level of interaction; Brand representation; Brand marketing support); Partnership (Creating attractiveness; Level of mutual trust; Quality information exchange; Consistency of interests).

To form a strategy for positioning the brand portfolio, it is necessary to assess the "brand molecule" of the brand and determine the levels of influence of all brands in the portfolio on the main brand and determine their position in the market.

Creating a brand portfolio molecule allows you to take into account all the links with which the brand intersects, the "molecule" helps to visually represent all the brands that can be included in marketing decisions; since the relative contribution of each brand in the opinion of consumers in the target market is represented by the size of the scope of each brand, you can see the relative value of individual brands: the larger the area, the higher the value; positioning areas in the brand molecule provides additional information that helps marketers differentiate analyzing brands.

Based on the results of the brand molecule, it is possible to build a positioning matrix for all participants in the brand portfolio according to the criteria of "brand position" and "segment thickness", which are key values for forming a brand positioning strategy. Positioning helps to distinguish the brand among other competitors in the minds of consumers. In the (table. 2) we create a matrix of brand portfolio positioning to the 'Rud' Company (PJSC “Zhytomyr Butter Plant”).

Table 2

\section{Brand portfolio positioning matrix for the 'Rud' Company}

\begin{tabular}{|c|c|c|c|}
\hline Model & Indicator & $\begin{array}{l}\text { Selection } \\
\text { of criteria }\end{array}$ & Characteristic \\
\hline \multirow{2}{*}{$\begin{array}{c}\text { Macromodel } \\
\text { X-Y-Z }\end{array}$} & $X$ & $\begin{array}{l}\text { Market } \\
\text { position; }\end{array}$ & $\begin{array}{l}\text { Occupying a central position } \\
\text { The company's activities are aimed at the middle-price market segment } \\
\text { (middle-segment); }\end{array}$ \\
\hline & $\mathrm{YZ}$ & Key figure; & $\begin{array}{l}\text { Product } \\
\text { The desire to form a positioning, which is based on the excellent } \\
\text { properties (quality) of the product; }\end{array}$ \\
\hline $\begin{array}{l}\text { Mesomodel } \\
\text { I-D-U }\end{array}$ & $\mathrm{U}$ & Uniqueness; & $\begin{array}{l}\text { The brand's ability to deliver benefits is better than its competitors. } \\
\text { The trademark "Rud" - provides the consumer with quality and safety, } \\
\text { is fully responsible for the impact on the environment, has a wide range } \\
\text { of products, uses new technologies and approaches in work; }\end{array}$ \\
\hline \multirow[b]{2}{*}{$\begin{array}{l}\text { Micromodel } \\
\text { a-b-e }\end{array}$} & $\mathrm{a}$ & attribute & $\begin{array}{l}\text { Emphasis on product characteristics; } \\
\text { The company's focus on new technologies, responsibility } \\
\text { for product safety and quality; }\end{array}$ \\
\hline & $a-b$ & $\begin{array}{l}\text { attribute } \\
\text { benefit }\end{array}$ & $\begin{array}{l}\text { Emphasis on the benefits associated with product characteristics; } \\
\text { A sense of confidence in the consumer, using the products } \\
\text { of the company "Rud". At this stage, it is important to enshrine } \\
\text { in the subconscious of the consumer a specific benefit from the product } \\
\text { and reinforce it RTB (reason to believe) - a reason to trust. }\end{array}$ \\
\hline
\end{tabular}

Source: author's development. 
Therefore, according to Rositer and Percy, the application for the position of the brand should look like this:

1. The activity of PJSC "Zhytomyr Butter Plant" is aimed at the middle price segment of the market and is based on the excellent properties (quality) of products;

2. Advertising of this brand should focus on providing a unique image (U), as well as emphasize the characteristics of the product and the benefits associated with this characteristic (a-b).

The choice of position and the implementation of the application for it should be considered in all methods of brand promotion. The use of this matrix allows you to qualitatively implement programs to promote the brand, based on positioning, when creating advertising messages.

Positioning is a process that helps to properly distance the company's products from competitors, make it more visible and understandable to the audience. With the help of positioning strategy, you can determine the place that the company will occupy in the minds of consumers in relation to other products.

Based on the above actions and calculations, the development of the algorithm for positioning the brand portfolio, which consists of: goal setting and assessment of the state of the company; determining the role of brands in the overall portfolio of the company; assessment of the state of the company's portfolio; building a brand molecule of the company's portfolio; determining the position of the brand (table. 3 ).

Research has shown that there are certain principles for choosing the direction of differentiation, those principles that allow to determine the distinctive properties for the promotion of branded products. The position of a product can be determined on the basis of its distinctive properties, on the basis of the needs it satisfies or the benefits.

Table 3

\section{Brand portfolio positioning algorithm}

Goal setting and assessment of the state of the company

conducting a survey

analysis of activity

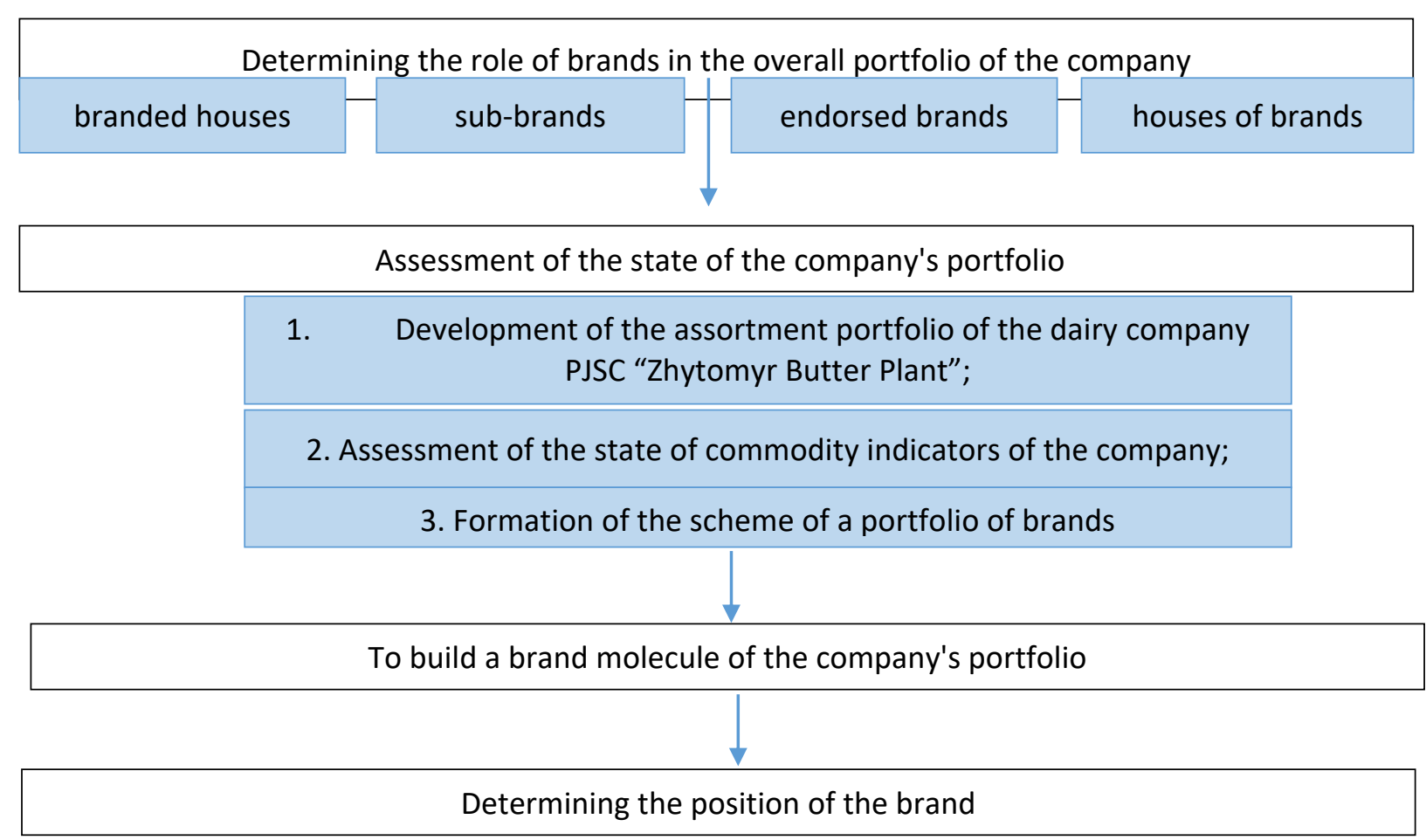

Source: author's development. 
The key principles in choosing the direction of differentiation include: value, uniqueness, superiority among others, affordability (at a price), profitability. It is worth noting that in the first step, the difference will be repeated by competitors, but the first step will form all the benefits and advantages of this.

In order to maintain competitive positions with the choice of positioning direction, it is necessary to ensure the differentiation of products from the products of competitors, which helps to remain in the subconscious of consumers, take a position in the market and move away from competitors. Differentiation by goods, service, personnel and image is used in marketing activity.

A key task in shaping the strategy of positioning and promotion of the brand and the overall portfolio of brands is to study what will serve as a basis that will distinguish them in the eyes of consumers. The sustainability of the company and the growth of profits depends on how clearly the approach to the consumer will be chosen.

\section{Conclusions.}

The position of a product can be determined on the basis of its distinctive properties, on the basis of the needs it satisfies or the benefits. The issue of brand portfolio positioning management based on molecular analysis has been worked out. It is advisable to consider positioning of the company's brand portfolio from the consumer's point of view on the brand. It was found that the molecular analysis of the brand portfolio involves focusing on certain positions of the brand in the market, which determines its competitiveness and affects the profitability and efficiency of the enterprise as a whole. The strong position of the brand allows you to gain consumer preferences for your own products, to form a loyal attitude of customers to the product.

\section{References:}

1. Aaker, D. (1996). Building Strong Brands. New York: The Free Press. [in English].

2. Domnin, V. N. (2020). Branding: textbook and workshop for secondary vocational education. Moscow: Yurayt. [in English].

3. Kapferer, J.-N. (2008). New strategic brand management: creating and sustaining brand equity long. London and Philadelphia: Kogan page. [in English].

4. Studref (2021). Pozitsionirovaniye [Positioning] <https://studref.com/348316/marketing/pozitsionirovanie> (2021, January, 05). [in Russian].

5. Rossiter, J., Percy, L. (2001). Advertising and promotion of goods. St. Petersburg: Peter. [in English].

6. Marketing.Webstandart.Net (2021). Molecular Branding <http://marketing.webstandart.net/node/1268> (2021, January, 05). [in English]. 